\title{
ARTYKUŁY
}

\section{KONCEPCJA LUDZKIEJ DUSZY I PROBLEM ANIMACJI W SYSTEMIE FILOZOFICZNYM ERIUGENY}

\begin{abstract}
Streszczenie. Rozważania nad ludzkim życiem prowadziły często do wniosku, że w człowieku istnieje pierwiastek życia, który nazwano duszą. Koncepcję człowieka, złożonego z duszy i ciała, przyjęły różne religie i systemy filozoficzne. Z tej koncepcji wynika problem animacji duszy, czyli próba określenia momentu, w którym dusza łączy się z ciałem, tworząc człowieka. W tym kontekście pojawia się również kwestia pochodzenia ludzkiej duszy. Na pytania o pochodzenie duszy i moment jej syntezy z materią ciała w ludzkiej matce proponowano w historii filozofii różne odpowiedzi. W systemie filozoficznym Eriugeny człowiek jest bytem, złożonym z duszy i ciała. Dusza jest istotą człowieka. Istotą duszy jest intelekt. Przejawem aktywności intelektu jest ludzki rozum. Istnienie duszy powoduje, że człowiek odkrywa, iż został stworzony do poznawania niepoznawalnego, własnego intelektu i Boga. Ludzka dusza istnieje przed powstaniem ciała człowieka. Każdy człowiek od chwili poczęcia posiada duszę, a moment zejścia duszy w materię ciała wymyka się ludzkiemu poznaniu. Ten moment jest tajemnicą Stwórcy.
\end{abstract}

Słowa kluczowe: Eriugena; Bóg; Stwórca; dusza; animacja

1. Wstęp. 2. Zarys wybranych koncepcji ludzkiej duszy. 3. Zarys wybranych koncepcji animacji. 4. Eriugeny koncepcja duszy. 5. Eriugeny koncepcja jednostkowienia duszy. 6. Eriugeny koncepcja zjednoczenia duszy z ciałem. 7. Problem animacji w systemie Eriugeny. 8. Zakończenie.

\section{WSTĘP}

Historia namysłu nad byciem człowieka w świecie prowadziła często do wniosku, iż ważnym aspektem ludzkiej egzystencji jest pewien element, który decyduje o byciu żywym, manifestujący się poprzez aktywność życiową. Postępujący namysł prowadził często do ujęcia tego elementu jako tchnienia życia, którym jest coś, co nazwano duszą. W antropologii filozoficznej dusza jest tym, co pozostaje zjednoczone $z$ materialnym ciałem i stanowi człowieka. Problemem 
ludzkiej duszy zajmowali się filozofowie przedsokratejscy oraz Sokrates, Platon i Arystotoles, którzy odcisnęli bardzo trwałe i znamienne piętno na koncepcjach późniejszych myślicieli. Pierwsi chrześcijanie dokonali syntezy różnych poglądów, dotyczących ludzkiej duszy, nawiązując do nauki Jezusa, tekstów Starego Testamentu i twierdzeń starożytnych Greków. Koncepcja Jana Szkota Eriugeny posiada swe źródła w chrześcijańskim neoplatonizmie, w myśli wschodnich Ojców Kościoła oraz w myśli Platona. Wraz z przyjęciem założenia, iż człowiek jest fenomenem, złożonym $z$ materialnego ciała i niematerialnej duszy, zrodził się problem określenia pochodzenia ludzkiej duszy, początków jej istnienia (zwłaszcza w relacji do materialnego ciała) oraz animacji - momentu połączenia duszy z materią, w wyniku którego powstaje człowiek. Problem animacji jest problemem nierozstrzygniętym i wydaje się wymykać ludzkiemu poznaniu w sensie absolutnym, lecz wypracowane na przestrzeni wieków stanowiska w tej kwestii mają istotne znaczenie dla wartości i ochrony życia.

\section{ZARYS WYBRANYCH KONCEPCJI LUDZKIEJ DUSZY}

Historia filozofii wskazuje, iż dusza bywała ujmowana jako pewien pierwiastek życia, którego obecność decydowała o tym, że człowiek, zwierzę lub roślina istnieją jako żywe - żyące byty. Historia filozoficznej antropologii wskazuje, iż ludzka dusza (tchnienie życia) jest obok materialnego ciała konstytutywnym elementem człowieka. Człowiek jest tym, kim jest, ponieważ posiada duszę i ciało. Dla filozofów przedsokratejskich tchnienie, warunkujące ożywienie i życie, oznaczało pewnego rodzaju inteligencję (Havelock 2007, 246). Giovanni Reale przyjmuje, że samo pojęcie duszy pochodzi od Sokratesa (Reale 2008, 316), który dokonał modyfikacji koncepcji życiodajnego tchnienia w kierunku indywidualnej ludzkiej duszy, której dobro przewyższa dobro materialnego ciała. W systemie filozoficznym Platona dusza ludzka to pierwiastek idealny, stanowiący istotę człowieka. Dusza uzdatnia do poznawania prawdy i dobrego 
postępowania oraz stanowi czynnik życia; jest niezrodzona (Platon 1999, nr 275a) i jako taka pozostaje wieczna (Platon 2005, nr 66e). Według Platona dusza ludzka w procesie poznawania prawdy powinna zerwać kontakt z ciałem (Platon 2005, nr 66e) i na drodze anamnezy zwrócić się w stronę świata idei (por. Stróżewski 2004, 231), ponieważ człowiek w swej istocie jest uwięzioną w ciele duszą. Arystoteles przyjmował za Platonem, że dusza stanowi istotę, a dokładnie esencję ludzkiego bytu, lecz nie akceptował platońskiej koncepcji niezależnego (od ciała) istnienia duszy. Dla Arystotelesa dusza jest formą naturalnego ciała, które posiada możność życia i nie może być nieśmiertelna (Arystoteles 2003, II, 1-3).

Chrześcijaństwo od czasów apostolskich przyjęło koncepcję ludzkiej duszy, w niektórych aspektach zgodną z myślą starożytnych Greków, choć przede wszystkim odwołującą się bezpośrednio do nauczania Jezusa Chrystusa. W czasach Jezusa, zwłaszcza w kręgach faryzejskich, dominował pogląd dotyczący ludzkiej duszy, oparty na koncepcji proroka Daniela. Przyjmowano, że człowiek jest jednością duszy i ciała. Nie akceptowano i często nie znano koncepcji platońskiej nieśmiertelnej duszy. Przyjmowano, że dusza to pierwiastek życia (Paciorek 2005, 318, 472), znikający w chwili śmierci, która jest końcem ludzkiej świadomości (Mędala 2010, 803). Wyznawcy Jezusa jako atrybuty podstawowe dla ludzkiej duszy przyjęli jej rozumność i nieśmiertelność. Po zakończeniu życia człowieka dusza opuszcza materię i staje przed sądem. Na końcu czasów odbędzie się sąd ostateczny, po którym nastąpi zmartwychwstanie sprawiedliwych, zgodnie z obietnicą Jezusa Chrystusa (J 11,25-26). Do greckiej koncepcji ludzkiej duszy nawiązywał św. Paweł, który czerpał z semickiej tradycji rozumienia duszy jako życiodajnego tchnienia i jednocześnie nawiązywał do koncepcji duszy jako pierwiastka, stanowiącego element odrębny od ciała. Zbawienie, którego dokonał Jezus, powoduje, iż ludzka dusza zyskuje nowy wymiar (Rz 8,10-13). Greccy Ojcowie Kościoła $z$ faktu, iż człowiek jest bytem stworzonym, wnioskowali, że nie może posiadać w sobie niczego, co byłoby niezniszczalne. Byt 
stworzony musiał być bytem śmiertelnym w każdym aspekcie, więc św. Justyn i św. Ireneusz przyjmowali istnienie śmiertelnej ludzkiej duszy. Dla Tertuliana ludzka dusza była swoistym rodzajem ciała o prostym i jednorodnym charakterze, ponieważ posiadała zdolność nawiązywania relacji z ludźmi i światem. Tertulian nie odróżniał duszy od ducha, więc duch ludzki również był tym samym swoistym rodzajem ciała. Niematerialność ludzkiej duszy akcentował św. Grzegorz Thaumaturgus, który głosił, że dusza jest czynnikiem poruszającym materię i dającym ludzkiemu ciału życie. Jako niematerialny byt nie posiada wagi, więc nie dodaje wagi ciału, co oznacza, że nie jest częścią ciała. Aktualnie Kościół katolicki naucza, że osoba ludzka, która została powołana do istnienia przez Boga na obraz i podobieństwo Stwórcy, jest istotą cielesną i duchową jednocześnie. Literalna interpretacja biblijnego tekstu zakłada, że Bóg ukształtował człowieka z materii, w którą tchnął tchnienie życia, wskutek czego człowiek ożył ( $\operatorname{Rdz} 2,7)$. Kościół zwraca uwagę, że w tekście biblijnym ludzka dusza często oznacza ludzkie życie (Mt 16,25-26; J 15,13), człowieka jako osobę ( $\mathrm{Dz}$ 2,41), wewnętrzną (Mt 26,38; J 12,27) i najcenniejszą (Mch 6,30; Mt 10,28) stronę ludzkiego bytu, co skłania do dwóch następujących wniosków: (1) człowiek jest wyjątkowym obrazem swego Stwórcy; (2) dusza ludzka jest duchową zasadą człowieka (Katechizm Kościoła Katolickiego 1994, 363).

\section{ZARYS WYBRANYCH KONCEPCJI ANIMACJI}

W Starym Testamencie czytelnik nie odnajduje bezpośrednich sugestii, dotyczących momentu, w którym nienarodzony jeszcze człowiek otrzymuje duszę. Potwierdzony zostaje oczywisty dla starożytnej medycyny fakt istnienia życia ludzkiego przed narodzeniem i materialnym oddzieleniem małego dziecka od organizmu matki ( $\mathrm{Rdz}$ 25, 24-26; Sdz 16,17; Jr 1,5; Iz 49,1; Ps 21,11; Ps 70,6), lecz brak informacji o niejako nadaniu ludzkiej istocie duszy (np. w stanie embrionalnym), która wraz z ciałem stanowi w pełni człowieka. 
Analogiczna sytuacja występuje również w tekście Nowego Testamentu (Łk 1,44; Gal 1,15), więc uprawnione wydaje się twierdzenie, iż Biblia nic wprost nie mówi o momencie, w którym materia łączy się z duszą, tworząc człowieka. Uprawnione wydaje się jednocześnie twierdzenie, iż Biblia wprost mówi o ludzkim życiu dziecka, poczętego i żyjącego $\mathrm{w}$ łonie matki, lecz jeszcze nienarodzonego i nieoddzielonego od organizmu matki. W pierwszych wiekach chrześcijaństwa szacunek dla żyjącego w łonie matki dziecka był wyraźnie wyartykułowany (Michalski 1975, 30, 195; Quacquarelli 1976, XIX/5), natomiast brak tego szacunku wiązał się z karą „wiecznego jeziora krwi i błyskawic uderzających w oczy" (Michalski 1975, 71). Wydaje się, że wymagany szacunek dla ludzkiego życia od jego poczęcia wśród pierwszych chrześcijan wynikał z przeświadczenia, że poczęte już życie nie jest tylko częścią organizmu matki, lecz zyskuje pewną podmiotowość i jest życiem już innej osoby. Człowiek to jednak nie tylko materia ludzkiego ciała, lecz również dusza i w tym kontekście istotnym wydaje się problem animacji - kwestia momentu nadania duszy ludzkiej materii. Starożytni myśliciele rozważali te problemy i rodzące się chrześcijaństwo zderzyło się z jednej strony z problemem animacji w ogóle, a $\mathrm{z}$ drugiej strony z dorobkiem starożytnych filozofów w tej kwestii. Do koncepcji Platona wydaje się nawiązywać Orygenes, który wprost nie zajmuje jednak stanowiska w sprawie określenia momentu oraz sposobu zejścia duszy w materię ludzkiego ciała. Orygenes przyjmuje, że nauka Kościoła nie określa, a tym bardziej nie precyzuje, czy dusza zostaje nadana materii wraz z nasieniem rodziców, w którym może być zawarta (np. przyczynowo lub substancjalnie), czy dzieje się to jakoś inaczej (Michalski 1975, 361). Nawiązując do Platona, Orygenes przyjmuje preegzystencję dusz i ich upadek w ludzkie ciało, które według Platona jest swego rodzaju więzieniem dla duszy. Orygenes zakłada, że podczas pierwotnego aktu stworzenia Stwórca powołał do istnienia tylko duszę. Upadek, który stał się konsekwencją grzechu pierworodnego, spowodował, że Stwórca powołał do istnienia ciała. Po grzechu istniejące uprzednio 
dusze upadają w ludzką materię, formowaną w łonach matek (Congourdeau 1989, 309).

Nawiązując do poglądów stoików, Tertulian przyjmował obecność ludzkiej duszy w ludzkiej materii, rozwijającej się w łonie matki. Nie precyzował dokładnie momentu zrodzenia duszy w ciele lub wniknięcia duszy w ciało, lecz stanowczo sprzeciwiał się koncepcjom zakładającym, iż dusza zostaje nadana ciału dopiero w momencie narodzin dziecka - przejścia z życia w organizmie matki do życia poza jej organizmem (Michalski 1975, 239-240). Tertulian uważał, że w łonie ludzkiej matki substancja duszy i substancja ciała powstają równocześnie, ponieważ podczas śmierci człowieka równocześnie, w jednym momencie, dochodzi do oddzielenia duszy od ciała oraz ciała od duszy. Śmierć jest oddzieleniem, więc początek życia jest połączeniem duszy i ciała (Michalski 1975, 241). Dowodem na równoczesne powstanie duszy i ciała jest według Tertuliana również zjawisko dziedziczenia przez dzieci różnych talentów i zdolności (Michalski 1975, 241). Tertulian przyjmował koncepcję jednoczesnej animacji, tzn. uważał, iż w jakimś jednym momencie, gdy powstaje materialny ludzki embrion, powstaje również w tym embrionie ludzka dusza. Ta koncepcja wykluczała animację sukcesywną, a więc wykluczała możliwość istnienia ludzkiego embrionu, który niejako oczekuje na swą duszę i istnieje jako preanimowana forma - byt tylko potencjalnie osobowy. Nowy człowiek powstaje z dwóch rodzajów nasion: duchowego (odpowiedzialnego za duszę) i cielesnego (odpowiedzialnego za materię). Nasiona te są zawsze połączone, więc koncepcja animacji sukcesywnej jest wykluczona (Michalski 1975, 241). Wydaje się, że koncepcja Tertuliana, określana jako traducjanizm, znosi ważną rolę Boga w powstawaniu nowych ludzkich istnień, ponieważ nowy człowiek otrzymuje materię i duszę w dwojakim, nierozdzielnym nasieniu rodziców (Congourdeau 1989, 310). Generowanie nowego życia zależy więc od woli rodziców i nie wymaga interwencji Stwórcy. Tertulian uważał, że poczęte ludzkie życie wymaga bezwzględnej ochrony (Michalski 1975, 217), lecz 
dopuszczał w skrajnych przypadkach możliwość zabicia dziecka w łonie matki. Do tych przypadków zaliczał np. takie położenie dziecka w łonie matki, które według ówczesnej medycyny mogło spowodować śmierć matki przy porodzie (Michalski 1975, 240).

Zwolennikami równoczesnej animacji ludzkiego embrionu byli patrystyczni Ojcowie chrześcijańskiego Wschodu: Grzegorz z Nyssy i Maksym Wyznawca. Wydaje się, iż zarysowując koncepcję animacji ludzkiej duszy w rozważanych Grzegorza z Nyssy i Maksyma Wyznawcy, nie sposób pominąć faktu, że Jan Szkot Eriugena w swoich rozważaniach egzegetycznych nawiązywał do starożytnych filozofów, natomiast w koncepcjach filozoficznych odwoływał się do ojców patrystycznych, w tym również do Maksyma Wyznawcy i Grzegorza z Nyssy, którego nie odróżniał od Grzegorza z Nazjanzu, więc odwoływał się do jednego Grzegorza Teologa (Grzegorzyca 2016, 147). Grzegorz z Nyssy przyjmował, iż człowiek jest bytem złożonym z jednej duszy i jednego ciała, co oznacza, że dusza ludzka i ciało muszą posiadać jeden wspólny początek. Nie istnieje więc, według Grzegorza, możliwość animacji sukcesywnej, ponieważ ani dusza nie może istnieć przed stworzeniem ciała, ani ciało nie może istnieć przed stworzeniem duszy, gdyż takie istnienie powodowałoby nieodwracalny konflikt człowieka samego z sobą, podzielonego jakimś upływem czasu pomiędzy istnieniem duszy lub ciała i ich połączeniem w ludzką, osobową jedność bytu człowieka. Według Grzegorza z Nyssy poczęta ludzka materia otrzymuje duszę natychmiast w chwili poczęcia (Congourdeau 1989, 311). Za koncepcją jednego początku ludzkiej duszy i ciała opowiadał się również Maksym Wyznawca, który wskazywał na konieczność obecności duszy już w pierwszym stadium istnienia ludzkiej materii z uwagi na samą organizację ludzkiego ciała i zapewnienie właściwego rozwoju nowego człowieka. Według Maksyma ludzkie ciało i dusza nie mogą istnieć oddzielnie, lecz ich istotą jest stanowienie człowieka. Ludzka natura nie istnieje poza ludzkimi osobami, więc ludzki byt jest od momentu poczęcia bytem osobowym - jest człowiekiem, który 
w jednym momencie otrzymał ciało z ludzkiego nasienia i duszę z woli Boga (Congourdeau 1989, 311).

Aktualnie Kościół katolicki wydaje się akceptować koncepcję patrystycznych Ojców - Grzegorza i Maksyma, jednak nie zawsze tak było, ponieważ chrześcijaństwo zachodnie na wiele stuleci zaakceptowało koncepcję animacji ludzkiej duszy, zaproponowaną przez Arystotelesa. Stagiryta przyjmował, że dusza ludzka jest formą ludzkiego ciała, więc analogicznie do innych bytów, złożonych z materii i formy, ludzka materia (ciało) może istnieć bez ludzkiej formy (duszy), tak jak glina może istnieć bez formy dzbana w warsztacie garncarza. Arystoteles postawił również pewne wymagania, dotyczące ludzkiej materii - tylko właściwie dobrana glina nadaje się na dzban, więc analogicznie tylko embrion, który właściwie się rozwinął i stał się odpowiednio bliski ludzkiej formie, może otrzymać duszę. Granice tego rozwoju miała określać starożytna filozofia i medycyna, według których (zdaniem Arystotelesa) materia ludzka mającego narodzić się chłopca otrzymywała duszę w czterdziestym dniu od dnia poczęcia, natomiast materia ludzka mającej narodzić się dziewczynki otrzymywała duszę w osiemdziesiątym dniu od dnia poczęcia. Kośció1 katolicki nie zaakceptował koncepcji Ojców wschodnich, lecz przyjął koncepcję Stagiryty i wypracował pojęcie preanimowanego embrionu oraz animowanego embrionu. Chociaż założono, iż obydwa embriony podlegają ochronie, to jednak nie przyjęto koncepcji osobowego życia ludzkiego w łonie matki od poczęcia. Koncepcje Grzegorza z Nyssy i Maksyma Wyznawcy nie znalazły właściwego uznania w nauczaniu Kościoła. Koncepcja traducjanizmu, zaproponowana przez Tertuliana (oparta o myśl stoików) została potępiona przez papieża Atanazego II w 498 roku. Rozwiązania, zaproponowane przez Orygenesa (oparte na myśli Platona), zostały potępione w 553 roku na II Soborze w Konstantynopolu. Zaakceptowano rozwiązania, zaproponowane przez Arystotelesa, jednak aktualnie Kościół odżegnuje się od tej koncepcji i wyraźnie nie akceptuje animacji sukcesywnej, opowiadając się za animacją równoczesną w chwili 
poczęcia. Kościół aktualnie przyjmuje, że nowe poczęte ludzkie życie jest zawsze życiem osobowym, a kategoria osoby odnosi się do człowieka lub do anioła, który jest bytem intelektualnym. Każdy człowiek to byt, łączący w sobie duszę i ciało, więc animacja sukcesywna jest wykluczona, a koncepcja animacji równoczesnej jest dla Kościoła słuszna, zwłaszcza że samo wcielenie odwiecznego Logosu - Syna Bożego oznaczałoby według koncepcji animacji sukcesywnej, że Jezus był przez jakiś czas preanimowaną formą materii, która po animacji stała się osobowym Synem Boga.

\section{ERIUGENY KONCEPCJA DUSZY}

W systemie filozoficznym Eriugeny drugą formę podziału natury stanowi stworzona natura stwarzająca (Eriugena 2009, 59-60), której źródłem jest mądrość Boga - niestworzonej natury stwarzającej. Ta mądrość to odwieczne Słowo Boże - Logos, w którym zostały ustanowione pierwotne przyczyny wzorcze (przyczyny prymordialne), stanowiące stworzoną naturę stwarzającą. Każde stworzenie zaistniało poprzez prymordialne przyczyny w Logosie (Eriugena 2010a, 127). Przyczyny moga przejść w swoje skutki dzięki działaniu Ducha (Eriugena 2010a, 121). Bóg Ojciec zradza Boga Syna - Logos, ustanawia w Nim przyczyny, a Duch Święty rozdziela je w skutki. Trzecia forma podziału natury to natura stworzona i niestwarzająca, stanowiąca całą rzeczywistość opisaną czasem i przestrzenią (Eriugena 2010b, 10). Zgodnie z pierwszymi wersetami Ksiegi Rodzaju ( $\operatorname{Rdz} 1,26-27)$ właśnie do trzeciej formy natury Eriugena zalicza człowieka, który został stworzony przez Boga wraz z innymi żywymi istotami. Gatunek ludzki należy do rodzaju zwierzęcego, jednak intelekt i rozum powodują, że sfera zwierzęcości zostaje w człowiek przekroczona (Eriugena 2012, 89) i człowiek wyraźnie przewyższa świat zwierząt. Cielesność człowieka manifestuje się poprzez zmysłowość, pożądliwość, gniew, popędy oraz siły wegetatywne. Duchowość człowieka manifestuje się poprzez poruszenia duszy, 
pamięć boskich rzeczy, intelekt, rozum i wewnętrzny zmysł. Wszystkie te władze powodują, że człowiek wymyka się zwierzęcości, by uczestniczyć w życiu aniołów (Eriugena 2012, 89-91), ponieważ intelekt to anielskie życie, którego odpowiednikiem jest w człowieku dusza (Eriugena 2010b, 397-399). Ulegając wolnej woli i czyniąc zło, człowiek może sam siebie zezwierzęcać bardziej, niż dane mu to zostało przez naturę. Kierując się w stronę duchowości, człowiek może ograniczać zwierzęcość do tej skali, która wynika z natury. Droga ku duchowości oparta jest na wiedzy i czynieniu dobra oraz wymaga pomocy Boga, który zawsze pragnie, aby człowiek wzrastał duchowo i odnawiał w sobie pierwotny obraz Stwórcy (Eriugena 2012, 101-103).

Eriugena uważał, że ludzka dusza jest prosta, a jej istotą jest intelekt. Dusza jest źródłem mocy i aktywności, przez którą intelekt manifestuje swe istnienie. Różne formy aktywności intelektu powodują, że istnieją różne władze ludzkiej duszy. Najwyższą władzą duszy jest intelekt - inteligencja - umysł - duch, którego możliwości działania Eriugena określa jako widzenie umysłu (Eriugena 2010b, 61), spojrzenie umysłu, ducha (Eriugena 2009, 105), wzrok kontemplacji (Eriugena 2010b, 113). Brian Stock uważa, że sam Eriugena redukuje ludzką duszę do intelektu, który manifestuje się w poznaniu: „Wobec tego kiedy mówię: "pojmuję, że jestem«, to czyż w tym jednym słowie, "pojmuję", nie zawieram trzech, wzajemnie niedających się oddzielić znaczeń? Przecież wykazuję i to, że jestem i że mogę pojąć, że jestem oraz że pojmuję, że jestem. Czyż nie widzisz, jak jednym słowem jest oznaczona i moja substancja, i moja moc i działanie? Ponieważ, jeślibym nie był, nie pojąłbym; ani nie pojąłbym, jeślibym nie posiadał mocy pojmowania; a owa moc nie jest we mnie uśpiona, lecz przechodzi w czynność pojmowania" (Eriugena 2009, 217; por. Stock 1977, 327-335). Stwórca, ustanawiając przyczyny wszystkiego, poznawał je, więc stwarzanie można uznać za akt tożsamy z poznaniem (Eriugena 2010b, 95; por. Trouillard 1983, 331-254). Gdy Eriugena pojmuje, że istnieje, to owo pojmowanie nie poprzedza jego istnienia, lecz stanowi jedność $z$ istnieniem (Eriugena 
2012, 163). Poznanie jest również wyrazem pewnej hierarchii, według której byt poznający jest doskonalszy od bytu, który jest poznawany. Stwórca ustanowił wszystkie rzeczy w człowieku, w którym zaistniały one w sposób doskonalszy, niż w samych sobie (Eriugena 2012, 155-157). Rzeczy w sobie samych nie poznają siebie, tak jak istniejąc w człowieku są poznawane przez człowieka. Stwórcą człowieka jest Bóg i człowiek nie zna w pełni siebie, choć poznawanie siebie jest jednym z najistotniejszych zadań ludzkiej natury. Człowiek został poznany przez intelekt Boga, więc Eriugena przyjmuje, że człowiek $\mathrm{w}$ swej istocie jest intelektualnym pojęciem w umyśle Boga. Człowiek posiada duszę, której istotą jest intelekt. Z intelektu wynikają władze duszy. Różne władze jednej duszy nie naruszają jej prostoty. Dusza ludzka w całości jest życiem, pamięcią, zmysłem wewnętrznym, rozumem i intelektem (Eriugena 2012, 95-97). Władze duszy nie naruszają jej jedności i prostoty, ponieważ dusza w całości w pełni utożsamia się z każdą z władz, które nie stanowią części składowych, lecz są aktywnościami, uruchomianymi w zależności od intencji i specyfiki rozpatrywanej wiedzy. Intelekt, rozum i zmysł wewnętrzny oraz ruchy ludzkiej duszy stanowią składowe części wewnętrznego człowieka. Istota ludzkiego intelektu jest niepoznawalna i do końca nie określona, ponieważ intelekt posiada potencję transcendowania natury ludzkiej i kierowania się w stronę transcendentnego Boga. Po uświadomieniu sobie, że Bóg jest transcendentny, intelekt dochodzi do wiedzy o własnej niewiedzy i wnioskuje, że Stwórca przekracza absolutnie wszystko. W granicach duszy funkcjonuje ludzki rozum, który posiada naturalną potencję ujmowania przyczyn prymordialnych, istniejących w umyśle Stwórcy. To ujmowanie zradza wiedzę po wyższej niewiedzy. Przyczyny posiadają swoje skutki, które stanowią obiekt zainteresowania dla aktywności trzeciej władzy duszy - ruchu wewnętrznego zmysłu. Trzecia władza posiada potencję ujmowania skutków przyczyn prymordialnych w sposób zapośredniczony przez ludzką wyobraźnię i zmysły (Eriugena 2010a, 173-175). Z aktywności ludzkiej duszy wynika proces poznania. Najwyższą władzę 
i aktywność duszy stanowi intelekt, więc ta władza jest również najistotniejszym elementem procesu poznania, a z tego wynika, że skoro intelekt naturalnie kieruje się w stronę Boga, to poznanie Boga jest podstawowym zadaniem ludzkiej duszy, stanowiącej istotę człowieka. Sytuacja człowieka jawi się więc jako dość skomplikowana, ponieważ człowiek nie poznaje do końca samego siebie, a jednocześnie został tak stworzony, że najwyższa aktywność jego duszy kieruje się w stronę Boga, o którym człowiek za pomocą niższej aktywności może się dowiedzieć, że jest On transcendentny. W procesie poznania człowiek dowiaduje się, że został powołany do procesu poznawania tego, co niepoznawalne. Poznając siebie, człowiek dowiaduje się o Bogu, ponieważ Bóg jest Stwórcą człowieka i dowiaduje się również o rzeczach, ponieważ zostały one stworzone w ludzkim umyśle. Człowiek żyje po to, aby poznawać Boga. Bez uwolnienia potencjału intelektu, który kieruje się w stronę Boga, czyli bez procesu i zadania sobie trudu poznawania Boga, człowiek nie jest w stanie właściwie postępować. Bez poznawania Boga nie można poznawać siebie i rzeczy (Beierwaltes 1966, 513). Stwórca uczynił człowieka na swój obraz i jakoś wszczepił w ludzką naturę pierwiastek swej światłości, więc człowiek może poznawać Boga poprzez doświadczanie jego obecności. Eriugena przyjmuje, że człowiek może poznać Boga, ponieważ Bóg może zechcieć, aby tak się stało. Dochodzi wówczas do silnego wsparcia ludzkiego umysłu przez Boże światło. Ta sytuacja jawi się jako pewne samopoznanie Boga, który umożliwia, by ludzki umysł poznawał źródło tego światła i Stwórcę tego umysłu (Eriugena 2000, 55-56). Eriugena przyjmuje, że w rozumnej części ludzkiej natury może być obecne Słowo oraz światło Boże i wówczas człowiek może trwać w procesie poznawania inteligibilnych rzeczy oraz swego Stwórcy (Eriugena 2000, 55). 


\section{ERIUGENY KONCEPCJA JEDNOSTKOWIENIA DUSZY}

W kontekście podjętego tematu niniejszego artykułu istotną kwestią wydaje się być problem jednostkowienia duszy ludzkiej. System filozoficzny Eriugeny wskazuje, że jednostkową różnorodność powodują przypadłości. Koncepcja powrotu teofanicznego (rozproszonego) stworzenia do spójności i prymordialnej doskonałości jednoznacznie wskazuje, że dla Eriugeny jednostkowość jest niedoskonałym i przemijającym stanem przypadłościowym. Jedna doskonała i spójna natura ludzka zaistniała jako prymordialna. Ta natura uczestniczyła w jednej duszy, rozumianej przez Eriugenę jako powszechne życie stworzone przez Boga w piątym dniu kreacji. Zgodnie z Księgq Rodzaju, według Eriugeny, w trzecim dniu kreacji Bóg stworzył prymordialną duszę, rozumianą jako substancjalna forma i moc nasienna, kierująca rozwojem nasion (Eriugena 2010b, 313-315). Ta moc przechodzi z poziomu przyczyn do zmysłowych form i kształtów, które realizują się poprzez narodziny (Eriugena 2010b, 43). W piątym dniu kreacji Bóg stworzył żyjącą duszę (Eriugena 2010b, 385; por. Kijewska 1999, 126-134), rozumianą jako ogólną formę życia świata (Eriugena 2010b, 385). Poprzez błędny wybór (grzech) natura ludzka doznała zejścia z prymordialnego do innego, rozproszonego stanu istnienia, ściągając do tego stanu całe stworzenie, ponieważ to stworzenie właśnie w ludzkiej, prymordilanej naturze zostało powołane do istnienia. Pozbawione prymordialnej jedności stworzenie doznało przypadłościowego ujednostkowienia. Dla Eriugeny oczywisty jest fakt, iż tak jak prymordialny człowiek uczestniczył w duszy - w życiu, tak również żyjący w rzeczywistości teofanicznej ludzie partycypują w naturze prymordialnej i posiadają dusze na zasadzie partycypacji w duszy prymordialnej - idei życia. W Periphyseonie Eriugena pisze: „W każdym wypadku bezsprzecznie twierdzimy to, czego poszukiwaliśmy, co odkryliśmy i wytłumaczyliśmy na podstawie prawdziwych argumentów, a mianowicie, że wszelkie życie, czyli dusza władająca ciałem, zaczęło istnieć jako dusza bądź życie 
na mocy uczestnictwa w jednym prymordialnym życiu albo duszy. Przyrodzony rozum nie dopuszcza, aby dusza całkowicie zarzuciła to uczestnictwo, niezależnie od tego, czy przejawia się ono w kierowaniu ciałem, czy nie" (Eriugena 2010b, 414). Eriugena zakłada powrót stworzenia do jego przyczyn, co oznacza powrót człowieka (i stworzenia) teofanicznego do rzeczywistości prymordialnej. Ten powrót będzie zniesieniem jednostkowości dla ogólności. Sama jednostkowość jest dla Eriugeny czymś przypadłościowym, a prawdziwą istotą rzeczy są wieczne i niezmienne racje, które pozostają zawarte w przyczynach prymordialnych. W Periphyseonie omawiany filozof pisze: „A z tego wynika, że wszelkie stworzenie nie posiada żadnej innej substancji oprócz tej racji, która została ustanowiona w Słowie Bożym w przyczynach prymordialnych, i dlatego nie można ustalić, czym ono jest, jako że przekracza wszelkie substancjalne określenie. Kiedy zaś na drodze rodzenia stworzenie przechodzi we właściwą zmysłową czy inteligibilną postać, to definiuje się je poprzez to, co je otacza i co jest jego przypadłością" (Eriugena 2012, 151). Celem stworzenia jest powrót do rzeczywistości prymordialnej (rajskiej), co jest możliwe dzięki naturalnym uwarunkowaniom (stan prymordialny jest stanem naturalnym dla ludzkiej natury) oraz dzięki łasce. Do stanu prymordialnego powróci każdy człowiek, jednak już tylko wybrani dostąpią przebóstwienia i będą kontemplować Boga, stając się (intencjonalnie) „bogami”. Dla Eriugeny przykładem opisanej sytuacji jest postać Jana Chrzciciela: „Przeto Poprzednik Pański był człowiekiem, nie bogiem. Pan zaś, którego był on Poprzednikiem, był zarazem człowiekiem i Bogiem. Poprzednik był człowiekiem, który za sprawą łaski miał stać się bogiem. Ten, którego poprzedzał, był Bogiem ze swej natury" (Eriugena 2000, 57). Według Eriugeny łaska uzdatniająca do przebóstwienia (moralnie i intelektualnie) jest każdemu człowiekowi udzielana stosownie do pewnej pojemności jego intelektu. Ta pojemność jest tak indywidualna i niepowtarzalna, że po powrocie rzeczywistości teofanicznej do prymordialnej stanie się zasadą ludzkiego jednostkowienia, „(...) ponieważ my i nasze 
intelekty nie są czymś od siebie różnym, jako że prawdziwą i najwyższą naszą istotą jest intelekt uszczególowiony kontemplacją prawdy" (Eriugena 2012, 177). Eriugena przyjmuje więc, że pojemność ludzkiego intelektu, który jest istotą ludzkiej duszy, decyduje o niepowtarzalności ludzkiego poznania, z którego wynika indywidualność ludzkiego bytu. Każdy intelekt dostępuje Bożego oświecenia (łaski), lecz intelekty w różny sposób uczestniczą w tym darze - z wolnej woli różnie reagują na ten dar i dodatkowo posiadają różne pojemności, czyli różne predyspozycje, różne zdolności percepcji. Jednostkowienie duszy przedstawia się więc następująco: (1) dusza ludzka uczestniczy w duszy powszechnej (prymordialnej); (2) istotą ludzkiej duszy jest intelekt; (3) intelekty z natury posiadają różną pojemność; (4) pojemność intelektu wpływa na zdolność percepcyjną łaski i jakość ludzkiego poznania; (5) wolna wola intelektu wpływa na relacje do łaski. Wydaje się, że można stwierdzić, iż źródłem jednostkowienia dusz jest pojemność intelektu i wolna wola, a więc w jakiejś mierze przypadłości, nad którymi człowiek może pracować, ponieważ może w sposób właściwy pielęgnować swój intelekt i kierować wolą tak, aby w sposób właściwy odpowiadały na Boże światło - łaskę. Troska o intelekt i wolę będzie prowadzić do przyjmowania łaski, a to powoduje niejako pokonywanie jednostkowości i wznoszenie się z rzeczywistości teofanicznej do prymordialnej.

\section{ERIUGENY KONCEPCJA ZJEDNOCZENIA DUSZY Z CIAŁEM}

Problem zjednoczenia duszy z ciałem w systemie filozoficznym Eriugeny jest ściśle związany z antropologią człowieka, która bezpośrednio wynika $\mathrm{z}$ aktu stworzenia przez Boga wszystkiego z niczego (Eriugena 2010b, 101). Dla Eriugeny powstanie stworzeń świadczy o działaniu trzech Osób Trójcy Swiętej. Trójca ujawnia się poprzez ustanowienie przez Boga Ojca w Bogu Synu (Logosie) przyczyn prymordialnych, a następnie przez działanie Ducha Świętego przy przechodzeniu przyczyn w ich skutki (Eriugena 2012, 195). Bóg 
uczynił wszystko jednym aktem stwórczym, który Księga Rodzaju opisuje w kolejności następujących po sobie sześciu intelektualnych dni stwarzania (Eriugena 2010b, 299). Te intelektualne dni nie stanowią porządku czasowego, lecz kolejność przechodzenia natury stworzonej i stwarzającej w naturę stworzoną i niestwarzającą. Stanowią przechodzenie przyczyn w ich skutki (Eriugena 2012, 193). Biblia opisuje dzieło stwórcze Boga w intelektualnych dniach stwarzania z uwagi na człowieka-czytelnika i jego zdolności poznawcze. Intelektualne dni są obrazem dla intelektów ludzkich. Eriugena przyjmuje, że w drugim dniu stwarzania Bóg uczynił pośrodku wód sklepienie, które jest granicą wszelkiej cielesności i kresem rzeczy widzialnych, poza którym nic cielesnego, czasowego i zmysłowego już nie istnieje (Eriugena 2010b, 283). Według Eriugeny rzeczywistość stworzona dzieli się na trzy natury: (1) duchową; (2) cielesną; (3) pośrednią (Eriugena 2010b, 285). Do natury pośredniej należą cztery proste elementy sklepienia: ogień, powietrze, woda, ziemia. Cztery elementy sklepienia posiadają cztery jakości: gorąco, wilgoć, zimno, suchość „(...) z których, zgodnie z fizyką, po dodaniu form, powstają wszystkie ciała materialne" (Eriugena 2010b, 335-337). Materialne ciało powstaje w wyniku połączenia cielesnych elementów, które po rozpadzie ciała wracają do pierwotnej formy istnienia. Duchowa sfera sklepienia odnosi się do początku tego, co duchowe wśród stworzenia, a więc do przyczyn prymordialnych. Sfera pośrednia (duchowo-cielesna) powoduje, że sklepienie skutecznie zakreśla granicę cielesności wśród stworzenia i przyczynia się do harmonii wszechświata (Eriugena 2010b, 287). Jednym $z$ istotnych elementów tej harmonii (na poziomie cielesnej rzeczywistości) jest to, iż gatunki mieszczą się w rodzajach. Człowiek przynależy do rodzaju zwierzęcego, jednak nie pozostaje w swym bycie ograniczony tylko do zwierzęcości, ponieważ przynależąc do niej jednocześnie przewyższa i wymyka się zwierzęcości, gdyż posiada intelekt i rozum. Sfera zwierzęcości jest w człowieku przekroczona poprzez posiadanie duszy (por. Kijewska 2005, 89), ponieważ intelekt w systemie Eriugeny 
jest istotą duszy, a rozum narzędziem intelektu. Człowieka można więc rozpatrywać w kategorii cielesności (zmysłowość, popędy, siły wegetatywne) oraz w kategorii duchowości (dusza, intelekt, rozum, pamięć rzeczy boskich). Zjednoczenie duszy z ciałem następuje więc jako zaistnienie pośredniej natury, łączącej w sobie duchowość z cielesnością. Zjednoczenie to wynika bezpośrednio z aktu stworzenia, ponieważ nie istnieje poza Bogiem żadna inna siła, zdolna do syntezy tak skrajnych porządków. Człowiek, który rodzajowo jest zwierzęciem, przekracza tą sferę, aby uczestniczyć w życiu aniołów (Kijewska 2005, 89-91). Aniołowie to osoby - intelekty. Życie anielskie to życie intelektualne, którego odpowiednikiem w ludzkiej naturze jest dusza (Eriugena 2010b, 397-399). Zjednoczenie duszy z ciałem to żyjący człowiek, w którym na mocy aktu stwórczego zjednoczenie to zostało dopuszczone i dokonane. Prymordialny człowiek został stworzony na obraz i podobieństwo samego Boga ( $R d z$ 1,26-27) i w ludzkiej naturze Bóg powołał do istnienia całość stworzenia. Agnieszka Kijewska zwraca uwagę, że „Powołanie do bytu człowieka rzuca nowe światło na dzieło sześciu dni stworzenia. Natura ludzka, będąc ontologicznym zwornikiem, streszczeniem, podsumowaniem dzieła stworzenia, jest jednocześnie warsztatem, w którym ono powstaje. Wszystko zostało bowiem stworzone nie tylko dla człowieka, ale i w człowieku i z tego względu całość rzeczywistości stworzonej jest zarówno uczestnikiem jego doskonałości, jak i podziela jego upadek" (Kijewska 2005, 80). Cielesność włącza człowieka do materialnego świata, natomiast dusza - do świata duchowego. Zjednoczenie duszy z ciałem powoduje, że człowiek jest ogniwem, które łączy w sobie dwa skrajnie różne porządki stworzenia. W człowieku - w warsztacie stworzenia, w którym stworzenie zaistniało, dusza i ciało sprawiają, że człowiek „,...) pojmuje jak anioł, rozumuje jak człowiek, odczuwa jak nierozumne zwierzę, żyje jak roślina, istnieje w ciele i duszy: ma zatem udział we wszelkim stworzeniu, ponieważ poza nim nie znajdziesz żadnego stworzenia" (Eriugena 2010b, 399-401). Zjednoczenie duszy i ciała powodują, że dla całego stworzenia natura 
ludzka stała się pośrednikiem „(...) w niej bowiem łączą się one ze sobą nawzajem i z wielości tworzą jedno. Jako że nie ma żadnego stworzenia od najwyższego po najniższe, którego nie dałoby się odkryć w człowieku, (...). Gdyż w nim schodzi się wszystko, co zostało przez Boga stworzone, i z różnych natur, niby z jakichś odległych dźwięków, tworzy jedną harmonię" (Eriugena 2010a, 59). Zjednoczenie duszy i ciała stanowi człowieka - jedną uporządkowaną całośc, jeden uporządkowany kosmos. „Człowieka przeto nazywa się całością, gdyż całe stworzenie stapia się w nim niby w jakimś tyglu" (Eriugena 2000, 60).

\section{PROBLEM ANIMACJI W SYSTEMIE ERIUGENY}

Eriugena przyjmuje, że w Logosie Stwórca ustanowił wieczne (lecz stworzone) przyczyny wszystkiego, poza którymi już nic więcej w rzeczywistości duchowej i materialnej nie powstaje. Jedność i prostota przyczyn nie wymaga wprowadzania dodatkowego porządku, który musiał zaistnieć po zaistnieniu skutków przyczyn (Eriugena 2010b, 65-67). Eriugena pisze: „I tak przyczyny (...), które Grecy nazywają ideami (...) są (...) wiecznymi i niezmiennymi racjami, według których i w których świat widzialny i niewidzialny jest kształtowany i kierowany. $Z$ tego powodu zasłużyły one na to, aby mędrcy greccy nazwali je pierwotnymi wzorami (prototypa), które Ojciec uczynił w swoim Synu, a przez Ducha Świętego rozdziela je w skutki i pomnaża" (Eriugena 2010a, 307-309). Wśród doskonałego stworzenia w przyczynach powołany do istnienia został również doskonały człowiek z prawie anielską naturą $\mathrm{i}$ transcendentną wobec jego samego tożsamością. Prymordialny człowiek był istotą duchową, czystym intelektem, posiadającym pewną wiedzę o Stwórcy i o sobie (Eriugena 2012, 169; por. Moran 1989, 160nn). Ta wiedza polegała na świadomości, iż człowiek nie może w sposób absolutny poznać ani Stwórcy, ani siebie samego, a jednocześnie ta sama wiedza nakazywała, aby nieustannie trwać w procesie poznawania Boga i siebie. Człowiek 
został powołany do istnienia jako prymordialny, więc ten stan jest stanem naturalnym dla człowieka, a każdy inny stan jest nienaturalny. Prymordialny człowiek realizował wolę Boga i w swej wolności nie podlegał jakiejkolwiek konieczności, ponieważ synchronizacja z wolą Boga powodowała, iż wola ludzka pragnęła tylko dobra. Ten człowiek istniał w doskonałej prostocie i pełnej jedności, więc nie podlegał podziałowi płciowemu. Prymordialny człowiek posiadał duchowe ciało i w duchowej rzeczywistości, analogicznie do bytów anielskich, dokonywało się zwielokrotnienie ludzi o niezniszczalnej naturze i godności równej aniołom (Eriugena 2010a, 63-65). W następstwie błędnego wyboru, nazywanego grzechem pierworodnym, prymordialny człowiek rozpoczął istnienie w rzeczywistości teofanicznej, doprowadzając do tej formy istnienia również stworzenie, które uprzednio w ludzkiej naturze zostało powołane do istnienia.

Problem animacji w systemie Eriugeny jest ściśle związany z interpretacją grzechu jako błędnego wyboru oraz przejścia istnienia natury ludzkiej z formy prymordialnej do teofanicznej. Według Eriugeny prymordialny człowiek posiadał wolną wolę, która umożliwiła nierozumne (samo)poruszenie, powodujące odwrócenie ludzkiego umysłu od Stwórcy (Eriugena 2010a, 373). W ten sposób zaistniał błąd (grzech), doprowadzający do zniesienia jedności człowieka prymordialnego (Trouillard 1973, 108). Natura ludzka, podzielona na kobietę i mężczyznę, jest najbardziej widocznym i powszechnym skutkiem zniszczenia jej pierwotnej jedności (Jeauneau 1980, 341-364). Błąd nie posiadał źródła w prymordialnym człowieku, ponieważ zło, zdaniem Eriugeny, nie może posiadać aspektów pozytywnych, więc błąd nie może posiadać substancjalnego fundamentu (Iohannis Scotti seu Eriugenae 2003, 120-121). Pomimo przyjętych założeń Eriugena przyznaje jednak, że bez substancjalnego podłoża błędny wybór mógł zaistnieć, ponieważ wolna wola umożliwiała przyjęcie kłamstwa za prawdę. Jan Szkot przyjmuje, że w zmyśle ludzkiej natury tkwiło pragnienie rozkoszy, wpływające na umysł, który powinien pełnić rolę strażnika prymordialnej (rajskiej) rzeczywistości - praporządku, 
ustanowionego przez Stwórcę dla dobra człowieka i reszty stworzenia. Eriugena zwraca uwagę, że po błędnym wyborze Stwórca nie potępił człowieka, lecz źródło zła, które wygenerowało się z nierozumnego wyboru oraz z namiętności duszy ludzkiej, co sprzeciwia się woli Boga i wykracza poza akt stwórczy (Eriugena 2012, 375). Ta refleksja Eriugeny wydaje się mieć fundamentalne znaczenie dla próby ujęcia problemu animacji w systemie Jana Szkota. Eriugena wyraźnie wskazuje, że prymordialny człowiek posiada duszę.

Istnienie duszy na poziomie prymordialnym oznacza spójność systemową, zgodnie z którą to, co duchowe, jako doskonalsze, zawsze wyprzedza i przewyższa to, co zmysłowe i cielesne. Istnienie duszy na poziomie prymordialnym jednoznacznie wskazuje, że dla Eriugeny problem animacji nie istnieje w tym kontekście, w jakim jest on rozpatrywany np. współcześnie, gdy stawia się pytanie o moment powołania do istnienia duszy dla powołanego do istnienia ludzkiego ciała, oraz o moment ich syntezy, w wyniku której powstaje człowiekosoba. W systemie Eriugeny w sensie absolutnym dusza poprzedza $\mathrm{w}$ istnieniu osobę ludzką, bytującą w świecie czasu i przestrzeni, lecz w kontekście ograniczonych możliwości ludzkiego poznania powołany do istnienia człowiek posiada już, istniejącą dla niego, jego własną duszę. Nie zachodzi więc możliwość, aby powołane do istnienia ludzkie ciało mogło funkcjonować w ludzkiej matce bez wcześniej istniejącej duszy. W ludzkiej matce powstaje życie człowieka teofanicznego - życie ludzkiej osoby. System Eriugeny zmusza oczywiście do refleksji nad punktowym momentem syntezy powołanego życia materialnego (biologicznego) z uprzednio istniejącą duszą, jednak odpowiedź na to pytanie wydaje się już na zawsze wymykać ludzkiej wiedzy - nawet w XXI wieku. W systemie Eriugeny czytelnik odnajduje rozwiązania, odsyłające ludzki intelekt do transcendencji i autor niniejszego artykułu przyjmuje, że tak również przedstawia się kwestia momentu syntezy duszy z początkiem życia biologicznego. Ten transcendentny moment wydaje się stanowić tajemnicę, nieprzekraczalny załom natury. 
Tak jak Biblia nic wprost nie mówi o momencie, w którym materia biologicznego życia łączy się z duszą, tworząc w łonie ludzkiej matki człowieka, tak również Eriugena nie wypowiada się wprost w tej kwestii. Koncepcja Eriugeny nawiązuje do koncepcji preegzystencji dusz Platona, natomiast do Platona nawiązuje również Orygenes, który nie zajmuje stanowiska w sprawie momentu i metody zejścia duszy w materię ludzkiego ciała, lecz przyjmuje preegzystencję dusz i ich upadek w ludzkie ciało. Eriugena przyjmuje, że Bóg ustanowił w Logosie prymordialne przyczyny - byty wieczne (wiecznością Logosu) i niezmienne, wśród których zaistniał również posiadający duszę doskonały człowiek o duchowej naturze, zbliżonej do natury aniołów. Ów człowiek dokonał błędnego wyboru (grzech pierworodny) i zszedł $z$ poziomu istnienia prymordialnego do istnienia teofanicznego w świecie czasu i przestrzeni. Orygenes przyjmowal, że Bóg stworzył tylko dusze, a po grzechu pierworodnym powołał do istnienia ciała. Grzech spowodował, że uprzednio istniejące dusze upadają w ludzką materię, która formuje się w łonach matek. Stanowisko Eriugeny jest zgodne z koncepcją Tertuliana w kwestii braku doprecyzowania dokładnego momentu syntezy duszy z ciałem i jest w stosunku do niego rozbieżne w kwestii możliwości preegzystencji dusz - Tertulian wykluczył preegzystencję przyjmujacc, iż w łonie ludzkiej matki substancja duszy i substancja ciała powstają równocześnie. Zwolennikami animacji równoczesnej byli również patrystyczni Ojcowie: Grzegorz z Nyssy i Maksym Wyznawca, do których Eriugena w wielu rozwiązaniach nawiązywał i do których często odwoływał się, jako do autorytetów, lecz w kwestii preegzystencji dusz bliższa była Eriugenie koncepcja Platona, wywiedziona z neoplatonizmu. Koncepcja Eriugeny jest spójna z koncepcją Arystotelesa w zakresie możliwości istnienia duszy bez materialnego ciała. Wydaje się, że koncepcja Eriugeny jest również spójna z aktualną koncepcją Kościoła katolickiego w zakresie animacji, która (zgodnie z jego nauczaniem) następuje już na bardzo wczesnym etapie zaistnienia ludzkiego embrionu. Moment zejścia duszy w ciało pozostaje 
nieuchwytnym, momentalnym procesem transcendentnym wobec ludzkiego poznania, jednak tak jak przejście człowieka prymordialnego do rzeczywistości teofanicznej było przejściem człowieka, tak analogicznie zaistnienie w ludzkiej matce człowieka na poziomie embrionalnym jest również zaistnieniem człowieka, a więc bytu osoby obdarzonej ciałem i potencją jego rozwoju oraz duszą, która połączyła się z tym ciałem w momencie tak wczesnym, że wymykającym się ludzkiemu poznaniu. Koncepcja Eriugeny jest rozbieżna $\mathrm{z}$ aktualną koncepcją Kościoła katolickiego w zakresie preegzystencji dusz, lecz ten fakt wynika wprost z teologii i doktryny Kościoła oraz neoplatonizmu Jana Szkota Eriugeny.

\section{ZAKOŃCZENIE}

W systemie filozoficznym Eriugeny to, co duchowe, sytuuje się wyżej od tego, co zmysłowe. Dusza ludzka stanowi istotę człowieka i w rzeczywistości teofanicznej jest swego rodzaju pierwiastkiem prymordialności w człowieku. Według Eriugeny dusza jest prosta, a jej istotą jest intelekt. Jedną z aktywności intelektu jest rozum. Bóg jest Stwórca człowieka i człowiek został poznany przez intelekt Boga. Jednym z najistotniejszych zadań ludzkiego intelektu jest poznawanie siebie. W toku tego procesu człowiek odkrywa, że istota ludzkiego intelektu jest niepoznawalna (w sensie absolutnym) dla ludzkiego intelektu. Jednocześnie jednak ten sam intelekt, bez poznania siebie, posiada zdolność transcendowania własnej natury i kierowania się w stronę Stwórcy. W toku tego procesu człowiek sam sobie potwierdza własną, szlachetną niewiedzę i odkrywa, że jest stworzeniem absolutnie transcendentnego Stwórcy. To odkrycie powoduje, że ludzki intelekt uświadamia sobie konieczność realizacji drugiego (obok procesu samopoznania) zadania, którym jest podjęcie wysiłku na rzecz poznania niepoznawalnego Stwórcy. Dzięki ludzkiej duszy, stanowiącej istotę człowieka, dzięki intelektowi, stanowiącemu istotę duszy i dzięki rozumowi, stanowiącemu aktywność intelektu, 
człowiek w procesie poznawania odkrywa, że został stworzony do poznawania rzeczy niepoznawalnych. Wydaje się, iż właśnie w tym procesie Eriugena upatruje szczęśliwości dla ludzkiego bytu w każdej rzeczywistości. Człowiek nie pozna Boga w sensie absolutnym, lecz Bóg może pozwolić, aby człowiek poznał w jakiejś mierze siebie i Stwórcę już w rzeczywistości teofanicznej. Po jej zniesieniu człowiek będzie poznawał Boga w rzeczywistości prymordialnej, już poza czasem i przestrzenią. Bóg jest nieskończony, więc dzięki ludzkiej duszy człowiek będzie uczestniczył w nieskończonym procesie poznawania niepoznawalnego Boga, doznając swego rodzaju przebóstwienia, które również będzie procesem bez końca, ponieważ Bóg jest nieskończony, a stworzenie nigdy nie stanie się Stwórcą.

W systemie filozoficznym Eriugeny najistotniejszym aktem stwórczym jest powołanie do istnienia doskonałych bytów prymordialnych, wśród których zaistniał doskonały człowiek, posiadający duchową naturę, duchowe ciało i anielską godność. Duchowy człowiek posiadał również duszę, co wydaje się mieć fundamentalne znaczenie dla problemu animacji. Tak jak byt prymordialny wyprzedza w istnieniu byt materialny, tak również ludzka dusza wyprzedza istnienie osoby - człowieka złożonego z duszy i ciała. Powołany do istnienia człowiek posiada już istniejącą dla niego jego własną duszę. Nie istnieje możliwość, aby w ludzkiej matce istniało ciało nowego człowieka bez wcześniej istniejącej duszy. Moment syntezy duszy z biologiczną materią na poziomie embrionalnym wydaje się mieć dla Eriugeny charakter załomu natury, tajemnicy wykraczającej poza ludzki intelekt i zarezerwowanej dla Stwórcy. Rozważając problem animacji wydaje się, że można przyjąć, iż w systemie Eriugeny występuje nawiązanie do Platona i Orygenesa w kontekście preegzystencji dusz oraz jednocześnie nie istnieje możliwość istnienia człowieka bez duszy. Zatem człowiek nawet na poziomie embrionalnym jest osobą, ponieważ posiada duszę, która wcześniej preegzystowała, aby zejść i zjednoczyć się z materią biologiczną w ludzkiej matce. 


\section{BIBLIOGRAFIA}

Arystoteles. (2003). Dzieła Wszystkie. Tom 3: O duszy. Tłum. P. Siwek. Warszawa: Wydawnictwo Naukowe PWN.

Beierwaltes, W. (1966). Das Problem des absoluten Selbstberwusstseins bei Johannes

Scotus Eriugena. (Divina ignorantia summa ac vera sapientia). Philosophisches Jahrbuch, 73(2), 264-284.

Bourke, V.J. (1994). Historia etyki. Tłum. A. Białek. Warszawa: Wydawnictwo Krupski i Spółka.

Congourdeau, M.H. (1989). Czy embrion jest osobą?. Kolekcja Communio. Kosmos i człowiek, 4, 309-311.

Eriugena, Jan Szkot. (2000). Komentarz do Ewangelii Jana z Homiliq do Prologu Ewangelii Jana. Tłum. A. Kijewska. Kęty: ANTYK.

Eriugena, Jan Szkot. (2009). Periphyseon. Księga I. Tłum. A. Kijewska. Kęty: Wydawnictwo Marek Derewiecki.

Eriugena, Jan Szkot. (2010a). Periphyseon. Księga II. Tłum. A. Kijewska. Kęty: Wydawnictwo Marek Derewiecki.

Eriugena, Jan Szkot. (2010b). Periphyseon Księga III. Tłum. A. Kijewska. Kęty: Wydawnictwo Marek Derewiecki.

Eriugena, Jan Szkot. (2012). Periphyseon. Księga IV. Tłum. A. Kijewska. Kęty: Wydawnictwo Marek Derewiecki.

Grzegorzyca, A. (2016). Jan Szkot Eriugena w kontekście narodowościowym, historycznym i filozoficznym. Studia z historii filozofii, 7(1), 141-155.

Havelock, E.A. (2007). Przedmowa do Platona. Tłum. P. Majewski. Warszawa: Wydawnictwo Uniwersytetu Warszawskiego.

Iohannis Scotti seu Eriugenae. (2003). Periphyseon, liber quintus. Red. É. Jeauneau. Turnholti: Brepols.

Jeauneau, É. (1980). La Division des sexes chez Grégoire de Nysse et chez Jean Scot Erigène. W: W. Beierwaltes, C. Winter (red.), Eriugena. Studien zu seinen Quellen, 341-364. Heidelberg: Universitätsverla.

Katechizm Kościota Katolickiego. (1994). Poznań: Pallottinum.

Kijewska, A. (1999). Księga Pisma i Ksiega Natury. Heksameron Eriugeny i Teodoryka z Chartres. Lublin: Wydawnictwo KUL.

Kijewska, A. (2005). Eriugena. Warszawa: Wiedza Powszechna.

Mędala, S. (2010). Nowy komentarz biblijny - Ewangelia wedtug świętego Jana.

Część 1. Częstochowa: Edycja św. Pawła.

Michalski, M. (1975). Antologia literatury patrystycznej. Tom 1. Warszawa: PAX. 
Moran, D. (1989). The Philosophy of John Scottus Eriugena. A Study of Idealism in the Middle Ages. Cambridge: Cambridge University Press.

Paciorek, A. (2005). Nowy komentarz biblijny - Ewangelia wedtug świętego Mateusza. Część 1. Częstochowa: Edycja św. Pawła.

Pismo Święte Starego i Nowego Testamentu w przektadzie z języków oryginalnych. (2000). (Redakcja zbiorowa). Poznań: Pallottinum.

Platon. (1999). Fajdros. W: Platon, Dialogi. Tom 2. Tłum. W. Witwicki. Kęty: Wydawnictwo ANTYK.

Platon. (2003). Państwo. Tłum. W. Witwicki. Kęty: ANTYK.

Platon. (2005). Fedon. W: Platon, Dialogi. Tom 1. Tłum. W. Witwicki. Kęty: ANTYK.

Quacquarelli, A. (1976). I Padri Apostolici: Traduzione, introduzione e note, Lettera di Barnaba. Roma: Città Nuova.

Reale, G. (2008). Historia filozofii starożytnej. Tom 1. Tłum. E.I. Zieliński. Lublin: Wydawnictwo KUL.

Stock, B. (1977). Intelligo me esse: Eriugena's "cogito”. W: Jean Scot et l'historie de la philosophie. Actes des colloques internationaux $N^{\circ} 561$ du CNRS, Laon 7-12 juillet 1975. Paris: CNRS.

Stróżewski, W. (2004). Ontologia. Kraków: Wydawnictwo Aureus - Wydawnictwo Znak.

Trouillard, J. (1973). Érigène et la théophanie créatirice. W: J.J. O’Meara, L. Bieler (red.), The Mind of Eriugena. Papers of Colloquium, Dublin 1970, 98-113. Dublin: Irish University Press.

Trouillard, J. (1983). La „Virtus gnostica” selon Jean Scot Érigène. Revue Théologie et de Philosophie, 115(4), 331-354.

\title{
THE CONCEPTS OF THE HUMAN SOUL AND ANIMATION IN ERIUGENA'S PHILOSOPHICAL SYSTEM
}

\begin{abstract}
Reflection on human life often led to the conclusion that there is a source of life within man, which was called the soul. Various religions and philosophical systems have assumed that man is composed of soul and body. The problem is to determine the exact moment when the soul joins the body and a human being is created. The origin of the human soul is also a problem. In the history of philosophy there have been many attempts to solve these problems. According to Eriugena, man has soul and body. The soul is the essence of man. The essence of the soul is the intellect. The manifestation of the activity of the intellect is the human mind. The soul makes man discover that he was created to learn about his own unknowable intellect and God. The human soul exists prior to the human body.
\end{abstract}


Every human being has a soul since conception, and the moment when the soul descends into the body eludes human cognition. This moment is a secret known only to the Creator.

Keywords: Eriugena; God; Creator; soul; animation

\section{ADAM GRZEGORZYCA}

Uniwersytet Opolski, Instytut Filozofii

(University of Opole, Institute of Philosophy, Poland)

grzegorzycaadam@gmail.com

DOI: 10.21697/spch.2021.57.A.01

Artykuł jest udostępniany na zasadach licencji Creative Commons (CC BY-ND 4.0 Międzynarodowe).

Zgłoszono: 7/08/2020. Zrecenzowano: 11/10/2020. Zaakceptowano do publikacji: 24/03/2021. 